\title{
THE VEGETATION OF A SEASONAL VÁRZEA FOREST IN THE LOWER SOLIMÕES RIVER, BRAZILIAN AMAZONIA.
}

\author{
Hans KLINGE', Joachim ADIS ${ }^{1}$, Martin WORBES ${ }^{1}$
}

\begin{abstract}
The species composition of the seasonal várzea forest growing on a bank of the Ilha de Marchantaria / lower Solimões-Amazonas River, Brazil was studied in an area of slightly less than one hectare. Two biomass plots were harvested. Forty-seven arboreal species representing 46 genera in 25 families were recorded. Tree density was 1086 per hectare. Total basal area was $45 \mathrm{~m}^{2} \mathrm{ha}^{-1}$. Mean species density was $6.5 \pm 1.98$ per $100 \mathrm{~m}^{2}$. The most abundant species were Crataeva benthamii (Capparidaceae), Laetia corymbulosa (Flacourtiaceae) and Vitex cymosa (Verbenaceae). The highest basal area per species was $10.2 \mathrm{~m}^{2}$ for Pseudobombax munguba (Bombacaceae). The common species are known to be typical floristic elements of the seasonal yarzea forest. Above ground dry biomass was equal to 97 and $255 \mathrm{t} \mathrm{ha}^{-1}$, respectively. Its chemical composition is characterized by comparatively high bioelement contents equal to 2.4 percent on the average. Calcium was the most important bioelement. Structure of the forest and age datings of trees allow the successional classification of the stands.
\end{abstract}

Key words: Amazon, bioelements, biomass, floodplain, seasonal varzea forest, species composition, structure

A Vegetação de uma Floresta Sazonal de Várzea no Baixo Rio Solimões, Região Amazônica Brasileira.

RESUMO - Estudou-se numa ârea de pouco menos de um hectare, a composição de espécies de uma floresta sazonal de várzea, a qual cresce numa elevaçăo da Ilha de Marchantaria / baixo rio SolimõesAmazonas. Fez-se colheita de duas parcelas de biomassa. Registrou-se 47 espécies arbóreas, representando 46 gêneros em 25 familias. A densidade arbórea foi de 1086 por hectare. A área basal total foi de $45 \mathrm{~m}^{2}$ $\mathrm{ha}^{-1}$. A densidade média de espécies foi de $6,5 \pm 1,38$ por $100 \mathrm{~m}^{2}$. As espécies mais abundantes e frequentes foram Crataeva benthamii (Capparidaceae), Laetia corymbulosa (Flacourtiaceae) e Vitex cymosa

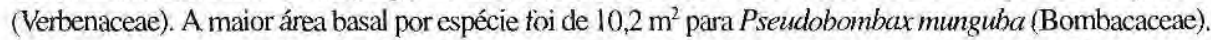
As espécies comuns são conhecidas como elementos florísticos típicos da floresta sazonal de várzea. A biomassa acima do chão foi de 97 e $255 \mathrm{t} \mathrm{ha}^{-1}$, respectivamente. A composição química é caracterizada por um conteúdo de bioelementos relativamente alto, igual a $2,4 \%$ na média. Cálcio foi o bioelemento mais importante. A estrutura da floresta e a datação da idade das árvores permite a classificação sucessional das formações arbóreas.

Palavras-chaves: Amazônia, bioelementos, biomassa, várzea, floresta sazonal de várzea, composição de espécies, estrutura

\section{INTRODUCTION}

Amazonian floodplain forests were first classified by PRANCE $(1979,1989)$ as seasonal vârzea (whitewater) and seasonal igapó (black- and clearwater) forests based on the water quality of the flooding rivers. A bioelement study of foliage, bark and wood from a variety of arboreal species sampled in both, seasonal várzea and seasonal igapó forests (KLINGE et al., 1983; 1984; KLINGE, 1986; KLINGE \& FURCH, 1991), yielded biogeochemical arguments which supported that classification. (For water and soil chemistry see K. FURCH et al., 1983).

1 Max-Planck-Institute for Limnology, Tropical Ecology Working Group. Postfach 165, D-24302 Plön, Federal Republic of Germany 
The second important characteristic of seasonal várzea and igapó forests is the monomodal flood pulse (PRANCE, 1979; JUNK et al., 1989; KLINGE et al., 1990) which, due to its intensity, effects a distinct seasonality along the Amazon and its main tributaries. This becomes visible as many tree species of the varzea floodplain shed their leaves during the submersion phase (WORBES, 1983) and form annual rings in the wood (WORBES, 1985; 1986; WORBES \& JUNK, 1989).

According to both the importance and the rapid development of the Amazonian várzea, the Tropical Working Group of the Max-Planck-Institute for Limnology at Plön in cooperation with the National Institute for Amazonian Research (INPA), Manaus, increased their research activities in the last ten years and focussed on a seasonal várzea forest at Itha de Marchantaria. Forest related investigations were carried out on morphology and chlorophyll content of tree leaves (B. FURCH, 1984), root respiration (SCHLÜTER, 1989), mycorrhiza of trees (MEYER, 1991), wood decomposition (MARTIUS, 1989), and litter fall (KLINGE et al., unpubl.).

This basic investigation on structure and species composition of some floristically different forest stands was carried out to complete the picture of the seasonal várzea forest ecosystem.

\section{Study Area}

The present study describes the species composition of a seasonal várzea forest, growing on the southern- most bank of Ilha de Marchantaria. The forest of the embankment measures, at most, $35 \mathrm{~m}$ in width. In the south, the bank is delimited by Lago Camaleão. The large island is situated in the lower Solimões River, approximately $15 \mathrm{~km}$ above its confluence with the Negro River (3'15's, $\left.58^{\circ} 58^{\prime} \mathrm{W}\right)$. The island consists of riverborn sediments of the Solimões River (IRION et al., 1983).

\section{MATERIAL AND METHODS}

A line was run in October 1982 from the eastern point of Ilha de Marchantaria to the west on the highest part of the embankment, over a distance of $1882 \mathrm{~m}$. Trees and climbers growing up to two meters on either side of the line were mapped, enumerated and identified to species level. L. Coelho, an experienced tree spotter of INPA, identified most species in the field. Unidentifiable plants were checked in INPA's herbarium. The circumference of all living trees and woody climbers was recorded on an area of $7528 \mathrm{~m}^{2} .75$ subplots of $4 \times 25$ $\mathrm{m}$ size were established. The plot No. 76 measured only $4 \times 7 \mathrm{~m}$ in area, since after $7 \mathrm{~m}$ the line touched the forest plot established by J. Adis. In his rectangular plot, $1500 \mathrm{~m}^{2}$ in area and named plot $\mathrm{A}$, he surveyed the forest vegetation in fifteen $10 \times 10 \mathrm{~m}$ subplots in the same manner as we did in the line transect. Top height of smaller trees in plot A was estimated using a pole of known length. Top height of taller trees was estimated by aid of gas-filled balloons, tied to a previously marked string of $30 \mathrm{~m}$ length. 
In all cases, the lower dbh-limit was established at $5 \mathrm{~cm}$, since during reconnaissance work it was found to be almost completely lacking in smaller trees.

Family Importance Values (FIV) (MORI et al., 1983) and relative Species Importance Values (SIV; equal to the sum of relative abundance, relative frequency and relative basal area) were computed. Dry weight of biomass samples was estimated and chemical analyses were carried out as described in KLINGE et al. (1983).

Two biomass plots, which were each $96 \mathrm{~m}^{2}$ and separated by meters, were established near to the eastern starting point outside of the transect.

\section{RESULTS}

\section{Floristic composition}

\section{Plant families}

Twenty-five plant families were recorded in the study area (Tab. 1). Leguminoseae sensu latu (including Mimosaceae, Caesalpinaceae, and Fabaceae) was richest in species. Six of the leguminous species belonged to the Caesalpinaceae and three each to the Fabaceae and Mimosaceae. The Annonaceae, Euphorbiaceae, Flacourtiaceae and Moraceae sensu lato (including Cecropiaceae) were also represented by three species per family. Seven families were represented by two species per family, and 13 families by a single species each.

The Leguminoseae sensu lato ranked highest, according to their Family Importance Values (FIV) equal to 45 (cf. MORI et al., 1983). They were followed (in decreasing order of FIV, see Tab. 1) by the Capparidaceae, Flacourtiaceae, Bombacaceae, Verbenaceae, Moraceae sensu lato, Lauraceae, Tiliaceae, and Euphorbiaceae. The remaining 16 families had low Family Importance Values which varied between 2 and 8 .

Comparing the floristic composition of the forest in plot A with the transect, it was observed that eleven families (Tab. 1) were recorded exclusively in the transect and two families exclusively in plot $\mathrm{A}$.

\section{Plant species}

Forty-seven woody plant species representing 46 genera were recorded in the study area (Tab. 2; Fig. 1). The total number of living trees was 980 (1086 per ha). Species Importance Values of Crataeva benthamii and Laetia corymbulosa were particularly high. These two species were both very abundant and very frequent. Pseudobombax munguba had the highest basal area $\left(10.2 \mathrm{~m}^{2}\right)$ of all species. Each of the last eight species in Table 2 was represented by a single individual.

The average species density of plot A was 1.1 species per $100 \mathrm{~m}^{2}$. Species density in the transect varied between 2 and 10 species per $100 \mathrm{~m}^{2}$. The mean species density was $6.46 \pm 1.985$ species per $100 \mathrm{~m}^{2}(\mathrm{~N}=76)$. Species number per 100 stems is 4.8 in the transect and 14.8 in plot $\mathrm{A}$.

Palms (Arecaceae) contributed insignificantly to the composition of the seasonal várzea forest under study. There were two species represented by 
Table 1. Plant families of the study area $\left(9028 \mathrm{~m}^{2}\right)$ in the Plot A (ADIS, unpubl.) in a seasonal várzea forest, Ilha de Marchantaria.

\begin{tabular}{|c|c|c|c|c|}
\hline Plant family & $\begin{array}{c}\text { Number of } \\
\text { species }\end{array}$ & $\begin{array}{c}\text { Relative tree } \\
\text { density }\end{array}$ & $\begin{array}{c}\text { Relative } \\
\text { basal area }\end{array}$ & FIV \\
\hline Caesalpiniaceae & 6 & 4.19 & 6.51 & 22.46 \\
\hline x Fabaceae & 3 & 5.92 & 216 & 13.96 \\
\hline Mimosaceae & 3 & 1.46 & 1.00 & 8.34 \\
\hline $\begin{array}{l}\text { Leguminosae sensu } \\
\text { lato }\end{array}$ & 12 & 11.57 & 9.67 & 44.76 \\
\hline Flacourtiaceae & & 19.23 & 9.35 & 34.46 \\
\hline Moraceae sensu lato ${ }^{1)}$ & & 6.11 & 5.58 & 17.57 \\
\hline Euphorbiaceae $\quad 1$ & 3 each & 6.75 & 1.13 & 13.76 \\
\hline Annonaceae & & 1.64 & 0.70 & 8.22 \\
\hline Subtotal 1 & 12 & 41.11 & 19.92 & 96.31 \\
\hline Lauraceae & & 2.55 & 9.74 & 16.21 \\
\hline Polygonaceae & & 0.82 & 3.29 & 8.03 \\
\hline x Lecythidaceae & & 1.55 & 0.26 & 5.73 \\
\hline Myrtaceae & 2 ecch & 1.37 & 0.14 & 5.43 \\
\hline Bignoniaceae & & 0.91 & 0.46 & 5.29 \\
\hline Areaceae & & 0.82 & 0.41 & 5.15 \\
\hline x Sapotaceae & & 0.64 & 0.19 & 4.75 \\
\hline Subtotal 1 & 14 & 8.66 & 14.49 & 50.59 \\
\hline Capparidaceae & & 25.52 & 8.95 & 36.43 \\
\hline Bombacaceae & & 3.37 & 25.57 & 27.90 \\
\hline Verbenaceae & & 8.57 & 8.20 & 18.73 \\
\hline x Tiliaceae & & 2.64 & 11.13 & 15.73 \\
\hline x Boraginaceae & & 1.73 & 4.22 & 7.91 \\
\hline x Polygalaceae & & 2.00 & 0.26 & 4.22 \\
\hline x Apocynaceae & 1 each & 1,28 & 0.10 & 3.34 \\
\hline xx Aquifoliaceae & & 0.36 & 0.31 & 2.69 \\
\hline$x$ Araliaceae & & 0.09 & 0.24 & 2.29 \\
\hline x Sterculiaceae & & 0.18 & 0.01 & 2.15 \\
\hline x Guttiferae & & 0.09 & 0.07 & 2.12 \\
\hline x Sapindaceae & & 0.09 & 0.01 & 2.06 \\
\hline xx Simaroubaceae & & 0.09 & 0.01 & 2.06 \\
\hline Subtotal & 13 & 46.01 & 59.08 & 127.63 \\
\hline Total & 51 & 99.97 & 100.00 & 296.99 \\
\hline
\end{tabular}

1) including the Cecropiaceae $x$ observed exclusively in the transect $\mathrm{xx}$ observed exclusively in plot $\mathrm{A}$ 
Table 2. Species composition in $9028 \mathrm{~m}^{2}$ of a seasonal várzea forest, Ilha de Marchantaria, Solimões River. Number of subplots in which species occurred (No. S.P.), number of individuals with dbh $5 \mathrm{~cm}$ or more (No. Tr.), basal area (B.A.) and relative species Importance Values Index (SIV). SIV is calculated for trees and shrubs only.

\begin{tabular}{|c|c|c|c|c|}
\hline Species & No. S. P. & NO. Tr. & B. A. $\left(m^{2}\right)$ & SIV \\
\hline Crataeva benthamil Eichl. in Mart. & 76 & 268 & 4.37 & 54.41 \\
\hline Laetia corymbulosa Spruce ex Benth. & 67 & 152 & 3.48 & 38.47 \\
\hline Pseudobombax munguba (Mart. \& Zucc.) Dugand & 18 & 36 & 10.17 & 32.59 \\
\hline Vitex cymosa Bert. ex Spreng. & 40 & 84 & 3.13 & 24.86 \\
\hline Luehea sp. & 24 & 29 & 4.64 & 19.53 \\
\hline Cecropia latiloba Miq. & 23 & 55 & 2.19 & 15.95 \\
\hline Nectandra amazonum Nees & 19 & 27 & 3.52 & 15.51 \\
\hline Macrolobium acaciifolium Benth. & 21 & 38 & 2.40 & 14.29 \\
\hline Pterocarpus amazonum (M. ex Benth.) Amsh. & 24 & 56 & 0.79 & 12.81 \\
\hline Alchornea discolor Endl. \& Poepp. & 21 & 61 & 0.40 & 11.71 \\
\hline Casearia aculeata Jacq. & 29 & 39 & 0.17 & 10.63 \\
\hline Cordia sp. & 10 & 19 & 1.76 & 8.41 \\
\hline Triplaris surinamensis Cham. & 7 & 7 & 1.24 & 5.27 \\
\hline Pseudoxandra leiophylla (Diels) R. E. Fries & 10 & 13 & 0.24 & 4.07 \\
\hline Tabernaemontana sp. & 10 & 13 & 0.03 & 3.55 \\
\hline Pithecellobium jupunba (Willd.) Urb. & 6 & 8 & 0.27 & 2.76 \\
\hline Eugenia sp. & 8 & 8 & 0.05 & 2.64 \\
\hline Annona sp. & 4 & 4 & 0.42 & 2.29 \\
\hline Crescentia amazonica Ducke & 4 & 7 & 0.08 & 1.77 \\
\hline Piranhea trifoliata Baill. & 5 & 5 & 0.07 & 1.74 \\
\hline Gustavia augusta L. & 3 & 6 & 0.07 & 1.44 \\
\hline Bactris sp. & 4 & 5 & 0.01 & 1.41 \\
\hline Astrocaryum jauary Mart. & 3 & 3 & 0.15 & 1.33 \\
\hline Tabebuia barbata (E. Mey.) Sandw. & 3 & 3 & 0.11 & 1.23 \\
\hline Neolabatia cuprea (Huber) W. A.Rodr. \& J. M. Pires & 3 & 4 & 0.04 & 1.15 \\
\hline Chlorophora tinctoria (L.) Gaudich & 3 & 3 & 0.07 & 1.12 \\
\hline Copaifera sp. & 2 & 3 & 0.11 & 1.01 \\
\hline llex inundata Poepp. ex Reiss. & 1 & 4 & 0.13 & 0.94 \\
\hline Cassia leiandra Benth. & 2 & 2 & 0.07 & 0.81 \\
\hline Labatia glomerata (Pohl ex Miq.) Radlk. & 2 & 2 & 0.02 & 0.68 \\
\hline Byttneria sp. & 2 & 2 & 0.01 & 0.64 \\
\hline Schefflera $s p$ & 1 & 1 & 0.10 & 0.57 \\
\hline Crudia amazonica Spruce ex Benth. & 1 & 1 & 0.07 & 0.50 \\
\hline Alchornea castaneifolia (Willd.) Juss. & 1 & 2 & 0.01 & 0.45 \\
\hline Psidium acutangulum A. DC. & 1 & 2 & 0.01 & 0.43 \\
\hline Inga sp. & 1 & 1 & 0.04 & 0.42 \\
\hline Sorocea duckei W. Burger & 1 & 1 & 0.04 & 0.41 \\
\hline Tachigalia sp. & 1 & 1 & 0.03 & 0.40 \\
\hline Calophyllum brasiliense Camb. & 1 & 1 & 0.03 & 0.39 \\
\hline Acosmium sp. & 1 & 1 & 0.03 & 0.39 \\
\hline Homalium sp. & 1 & 1 & 0.01 & 0.33 \\
\hline Simaba guianensis Aubl. & 1 & 1 & 0.01 & 0.33 \\
\hline Licania armenica (Nees) Kosterm. & 1 & 1 & 0.01 & 0.33 \\
\hline
\end{tabular}

Lianas:

Polygalaceae 1

Machearium sp.

Dalbergia $\mathrm{sp.}$

Paullinia sp. 


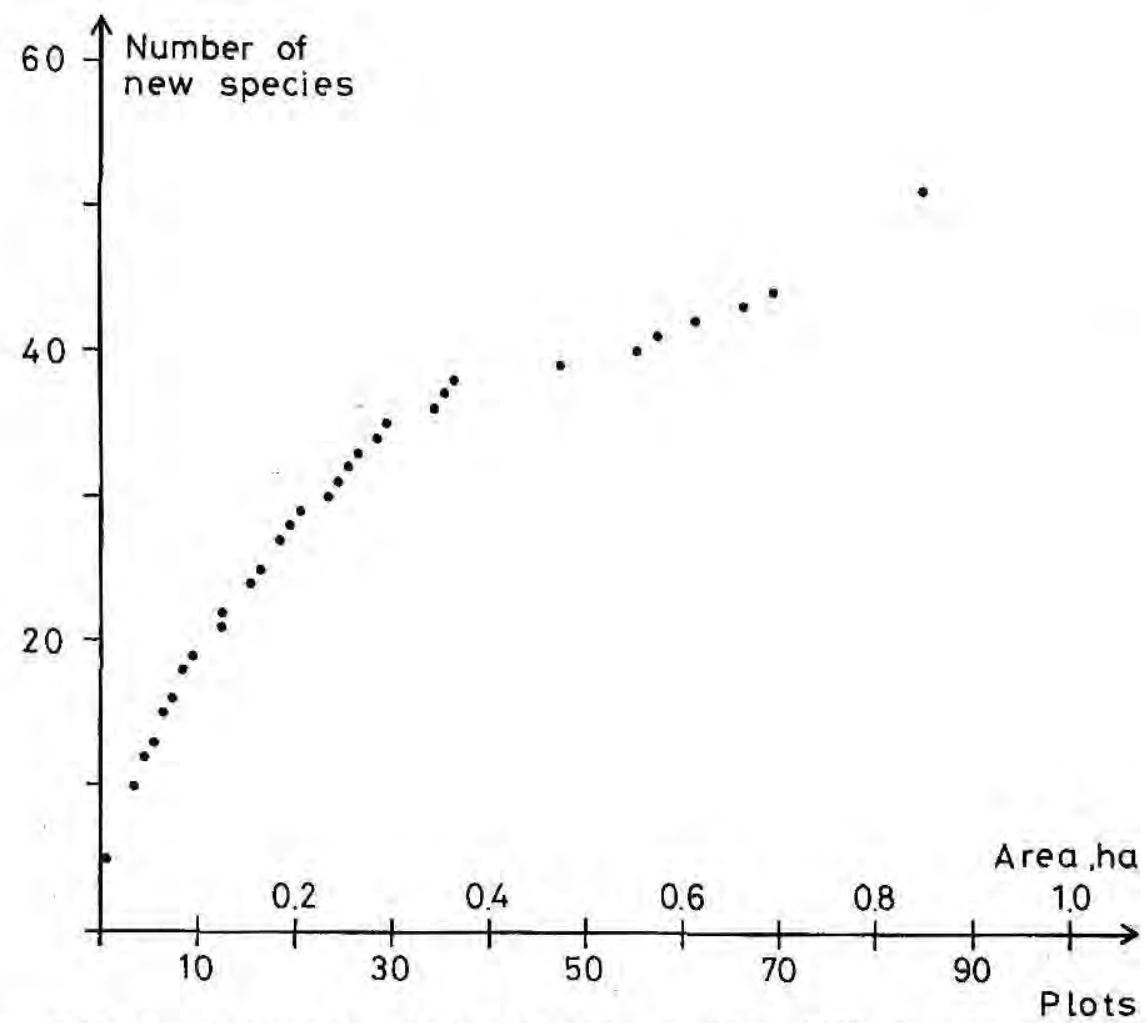

Figure1. Number of additional species found by adding an additional $100 \mathrm{~m}^{2}$ quadrat to the sample size, seasonal várzea forest, Ilha de Marchantaria.

less than 1 percent of the individuals. Woody climbers were represented by four species. Climbers were conspicuous at the forest floor, as they occasionally formed dense tangles, which were not supported by a tree. Epiphytes in the canopy/trunk area were rare and mostly represented by Orchidaceae.

\section{Forest structure}

\section{Diameter at breast height and top height of trees}

Maximum diameter at breast height (dbh) was $103.8 \mathrm{~cm}$ for a Pseudobombax munguba tree growing in the transect. Other species represented by big trees were Luehea sp., Nectandra amazonum, Cordia sp., Triplaris surinamensis, and Macrolobium acaciifolium.

The distribution of the dbh size classes illustrated a typical J-shaped curve (Fig. 2), as shown for various other tropical forests (CAMPBELL et al., 1986; LAMPRECHT, 1986)

Basal area varied between 8 and $131 \mathrm{~m}^{2} \mathrm{ha}^{-1}$ in the 76 plots of the transect and was $65 \mathrm{~m}^{2} \mathrm{ha}^{-1}$ in plot A. The value of the study area was $45 \mathrm{~m}^{2}$ ha $^{-1}$. The basal area of Amazonian forests rarely surpasses $40 \mathrm{~m}^{2}$ per ha (PIRES, 1984). LAMPRECHT (1972) 




Figure. 2. dbh-class distribution of 699 trees $(\mathrm{dbh}>10 \mathrm{~cm})$ sampled in the study area of a seasonal várzea forest, Ilha de Marchantaria.

reported basal area values between 40 and $60 \mathrm{~m}^{2}$ per ha for mountain forests of South America.

Measurements of top height of trees existed for 385 trees from plots $\mathrm{A}$ and $\mathrm{W}$ (the latter established in the central part of the island by WORBES, 1983), and the two biomass plots. This casual selection of the total sample represented some 39 species. Species represented by at least nine individuals for which top height and dbh data were available, are depicted in Figure 3.

Maximum top height of trees was $28 \mathrm{~m}$. In plot $\mathrm{W}$ this height was erached by several Pseudobombax munguba trees, forming the canopy roof (Tab. 3). Tallest $P$. munguba in plot A, also forming the canopy roof, reached only $25 \mathrm{~m}$ in height. $P$. munguba is a light demanding species, which does not regenerate in a closed forest. This is deduced from the obser- vation that there was no representative below $14 \mathrm{~m}$ in height and smaller than $15 \mathrm{~cm}$ in dbh (see Fig. 3). Single individuals of Pterocarpus amazonum and Crataeva benthamii reached top heights of about $25 \mathrm{~m}$.

$C$. benthamii was, however, mostly represented by considerably lower trees. There were relatively few species (like Casearia aculeata or Tabernaemontana sp.), which as single trees occurred only below $5 \mathrm{~m}$ in height. The majority of the species forming the main canopy was intermediate in height (Tab. 3). Crataeva benthamii and Laetia corymbulosa mostly composed the lower canopy. Luehea sp., Macrolobium acaciifolium, Nectandra amazonum, and Pterocarpus amazonum represented the upper canopy.

Cecropia latiloba presented a special case. Usually it formed pure stands or was dominant, as in biomass 

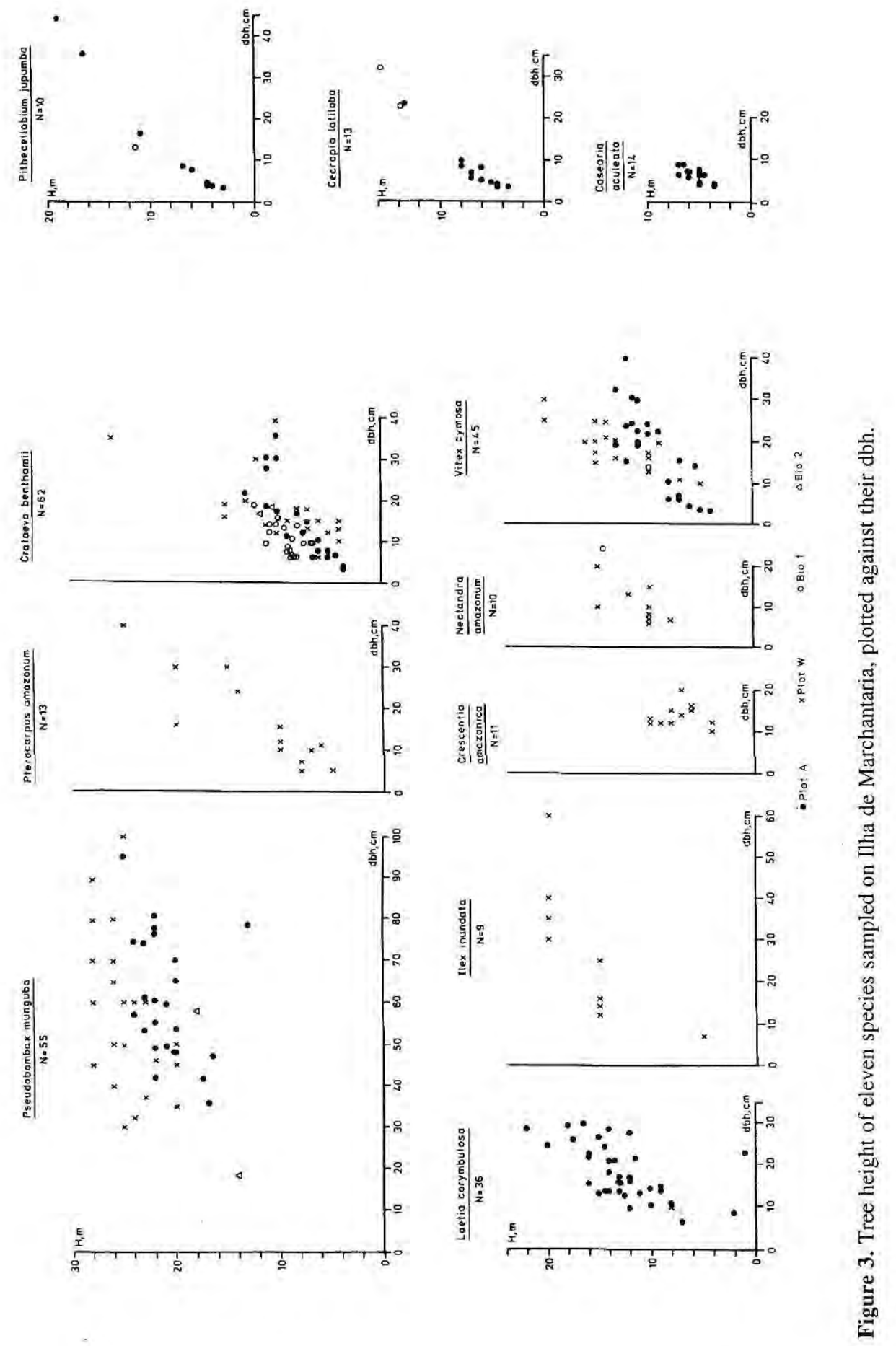
plot 1 . Occasionally this species was represented by isolated and relatively small trees under the closed canopy of the forest. More often, it occurred in groups outside the forest or at the forest fringe, where the ground was not covered by grasses.

There was a simple structured stand dominated by Cecropia latiloba forming the canopy roof at a height of $15 \mathrm{~m}$, under which a dense vegetation composed almost exclusively by Crataeva benthamii had developed (biomass plot 1, Tab. 4). Biomass plot 2 represented a stand type from which Cecropia latiloba was absent. The canopy roof was encountered at about 20 $m$ height (Tab. 5). Although less dense, the stand was richer in species. The lower canopy was composed exclusively by Crataeva benthamii.

Plot W represented a stand clearly dominated by Pseudobombax munguba. This species formed the canopy roof at a height of $28 \mathrm{~m}$ (WORBES, 1986). The vertical sections beneath this canopy were dominated by different species (Laetia corymbulosa the section $15-20 \mathrm{~m}$ above ground, Vitex cymosa the section $10-15 \mathrm{~m}$ above ground, and casually Crataeva benthamii the two sections).

The space in the three stands from ground level to $3 \mathrm{~m}$ above ground was free of tree crowns as it was in the forest, except for the few low growing species like Tabernaemontana sp. and Casearia aculeata.

\section{Above ground biomass and bole volume}

Species contribution to above ground biomass and bole volume of two small plots is given in Tables 4 and 5. The taller stand (biomass plot 2) with fewer but bigger trees had a basal area of $95.7 \mathrm{~m}^{2}$ $\mathrm{ha}^{-1}$, which was 2.5 times greater than in the other plot. Its above ground biomass of $257.6 \mathrm{t} \mathrm{ha}^{-1}$ was 2.4 times larger. Its bole volume was 4.35 times larger.

In biomass plot 1 , the upper canopy was composed exclusively of Cecropia latiloba. While contributing about one third to both basal area and above ground biomass, this species contributed about 50 per cent to the total bole volume. Crataeva benthamii dominated the lower canopy, contributing about two thirds to both basal area and above ground biomass, and about 50 per cent to the total bole volume. Vitex cymosa and Copaifera sp. contributed insignificantly to the totals of the stand.

East of this plot a pure stand of $\mathrm{Ce}$ cropia latiloba occurred.

In biomass plot 2 Luehea sp. and Pseudobombax munguba, which composed the upper canopy, together contributed about three quarters to the basal area, the above ground biomass and the bole volume, Crataeva benthamii, a member of the lower canopy, contributed comparatively more to the total stand than the other four species.

The vegetation of plots $\mathrm{A}$ and $\mathrm{W}$, which was dominated by big trees of Pseudobombax munguba, had a bole volume of 554 and $696 \mathrm{~m}^{3}$ ha $^{-1}$, respectively.

\section{Bioelements of the above ground} biomass

The average bioelement content of the dry above ground biomass of both biomass plots is given in Table 6 .

The bioelement contents of both plots differed slightly, due to their different species composition. Calcium 
Table 3. Vertical classification of tree species in biomass plots 1 and 2, Plot A and in Plot W in the central part of the island (cf. WORBES, 1983).

$<10 \mathrm{~m}$

(Willd.) Juss.

Casearia aculeata

Jacq.

Copaifera sp.

Crescentia amazonica

\section{Ducke}

Gustavia augusta L.

Mollia sp.

Pithecellobium inaequale

(H.B.K.) Benth.

Pseudoxandra polyphleba

R.E. Fries

Psidium acutangulum

A. DC.

Simaba guianensis

Aubl.

Tabebuia barbata

(E, Mey.) Sandw.

Tabernaemontana sp.

Trichilia singularis

\section{DC.}

Zanthoxylum compactum

즐 (Huber ex Albuq.) Waterm.

10-20m

Annona sp. I

Annona sp. II

Casearia aculeata

Jacq.

Cecropia latiloba

Miq.

Crataeva benthamii

Eichl. in Mart.

Elaeoluma glabrescens

(Mart. \& Eichl. ex Miq.) Aubr.

llex inundata

Poepp. ex Reiss.

Luehea sp.

Macrolobium acaciifolium

Benth.

Matayba macrolepsis

Radlk.

Mouriri guianensis

DC.

Nectandra amazonum

Ness.

Pithecellobium jupunba

(Willd.) Urb.

Rourea sp.

Sorocea duckei

W. Burger

Vitex cymosa

Bert. ex Spreng. 20-25m $<25 \mathrm{~m}$

Eschweilera sp.

Pseudobombax munguba

Labatia glomerata

(Mart. \& Zucc.) Dugand

(Pohl ex Miq.) Radlk.

Laetia corymbulosa

Spruce exBenth.

Luehea sp.

Piranhea trifoliata

Baill.

Pterocarpus amazonum

(M. ex Benth.) Amsh.

Swartzia sp.

Triplaris surinamensis

Cham. 
was the most abundant bioelement. Potassium followed next. Nitrogen ranked third and magnesium fourth. The least abundant bioelement was phosphorus. Among the alkali- and alkali-earth metals calcium was dominant, followed by potassium. The nitrogen/ phosporus ratio was below $20: 1$.

\section{DISCUSSION}

According to the classification of Amazonian inundation forests (PRANCE, 1979; 1989; KLINGE \& FURCH, 1991), the forest under study is easily identified as seasonal várzea forest. The annual flooding by the whitewater of the Solimões-Amazon River has two major consequences which differentiate this biotope from a non-flooded Amazonian "terra firme" forest:

1) The monomodal flood pulse (JUNK et al., 1989) causes, in a distinct seasonality, an annual change between favorable and poor growth conditions for the tree vegetation. Tree species settling in the floodplains require the ability to adapt to prolonged inundations (cf, JUNK, 1989);

2) The flooding by the nutrient rich whitewater (FURCH et al., 1983) and the annual sedimentation result in a comparable high soil fertility (WORBES, 1986) and a high bioelement content in all compartments of the trees (Tab. 6). The bioelement content of the várzea vegetation exceeds those from the Amazonian terra firme considerably and reaches values of tree stands in Panama (KLINGE, 1976).
Differences between terra firme and floodplain forests are visible in species composition and appearance of dominant families. In the Amazonian terra firme forest the leading families are Bombacaceae, Burseraceae, Chrysobalanaceae, Lauraceae, Lecythidaceae, Leguminoseae sensu lato, Moraceae, Sapotaceae, and Vochysiaceae (BALSLEV et al., 1986; KLINGE et al., 1975; PRANCE et al., 1976). Myrtaceae is the dominant family of the Bahian terra firme forest (MORI et al., 1983). Of the mentioned families, the Burseraceae, Chrysobalanaceae and Vochysiaceae apparently play no major role in the seasonal várzea forest of the lower Solimões River. Arecaceae are mentioned as dominant in both the tidal várzea forest and the floodplain forest. The abundance of palms in tidal várzea forest has been stressed by HUECK (1966), PIRES (1976) and PIRES \& PRANCE (1985). In the seasonal várzea under study, forest palms are an insignificant floristic element. Among the leading families of this forest type are the Capparidaceae and Flacourtiaceae, families little represented in Amazonian terra firme forest.

According to DUCKE \& BLACK (1954), HUECK (1966), GESSNER (1968), BRAGA (1979), PRANCE $(1979,1989)$, and PIRES \& PRANCE (1985) typical floristic elements of the seasonal várzea forest are, among others, Pseudobombax munguba, Vitex cymosa, Piranhea trifoliata, Crescentia amazonica, Nectandra amazonum, Gustavia augusta, and Crataeva benthamii. All 
N Table 4. Species contribution to above ground biomass, bole volume and basal area of a seasonal várzea florest (biomass plot 1), Ilha de Marchantaria.

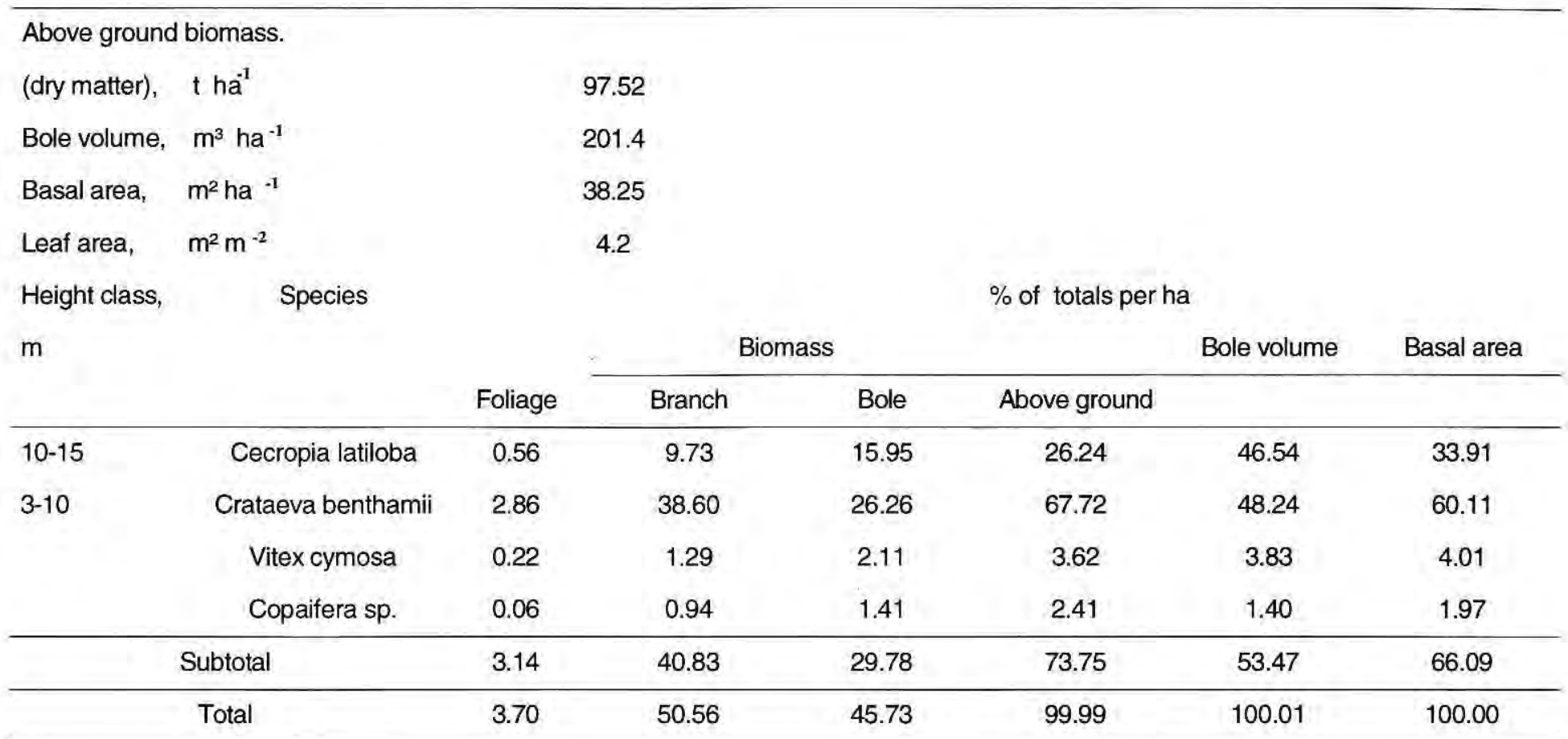


그 Table 5. Species contribution to above ground biomass, bole volume and basal area of a seasonal várzea forest (biomass plot 2), Ilha de Marchantaria.

\section{Above ground biomass.}

(dry matter), $\mathrm{t} \mathrm{ha}^{-1}$

257.6

Bole volume, $\mathrm{m}^{3} \mathrm{ha}^{-1}$

876.8

Basal area, $\mathrm{m}^{2} \mathrm{ha}^{-1}$

Leaf area, $\mathrm{m}^{2} \mathrm{~m}^{-2}$

95.7

3.3
Species

m

$15-20$

Luehea sp.

Pseudobombax munguba

Polygalaceae (climber)

$\frac{\text { Subtotal }}{10-15}$

Nectandra amazonum

Annona sp.

Macrolobium acaciifolium

Pithecellobium jupunba

Pseudobombax munguba

\begin{tabular}{ccc}
\hline Subtotal & & 0 \\
\hline $3-10$ & Crataeva benthamii & 0.56 \\
& Total & 0.22
\end{tabular}

\begin{tabular}{cccccc} 
& \multicolumn{3}{c}{ Biomass } & & \% of totals per ha \\
Foliage & Branch & Bole volume & Basal area \\
\cline { 2 - 6 } 0.21 & 25.76 & 26.24 & 52.21 & 54.82 & 47.83 \\
0.09 & 6.34 & 9.57 & 16.00 & 29.40 & 28.36 \\
0.08 & 1.23 & 0.84 & 2.15 & n.d. & 0.55 \\
\hline 0.38 & 33.33 & 36.65 & 70.36 & 84.22 & 76.74 \\
\hline 0.11 & 6.87 & 2.55 & 9.53 & 4.06 & 5.13 \\
0.27 & 3.87 & 0.72 & 4.86 & 2.17 & 3.32 \\
0.11 & 0.35 & 3.10 & 3.56 & 2.04 & 2.44 \\
0.07 & 0.55 & 1.43 & 2.05 & 0.96 & 1.53 \\
0 & 0.16 & 1.19 & 1.35 & 2.14 & 2.80 \\
\hline 0.56 & 11.80 & 8.99 & 21.35 & 11.37 & 15.22 \\
\hline 0.22 & 5.00 & 3.08 & 8.30 & 4.39 & 8.03 \\
\hline 1.16 & 50.13 & 48.72 & 100.01 & 99.98 & 99.99 \\
\hline
\end{tabular}


these species have been recorded in our study area.

Species which were recorded on the terra firme (CAMPBELL et al., 1986) and in the present study are Gustavia augusta and Piranhea trifoliata. However, studies on terra firme and adjacent floodplain forests in the Amazon region show concurrences of $18 \%$ (BALSLEV et al., 1986) and 45\% (CAMPBELL et al., 1986) on species level.

The effects of flood pulse and soil fertility may explain the comparable low species diversity of the várzea floodplain (BONGERS et al., 1988). Not more than $250-300$ tree species are presently recorded from the region of the lower Solimões River (KLINGE et al., 1983; REVILLA, 1991; WORBES, 1983; this study). This number of species can be found in one hectare or less on the terra firme. In terms of species per 100 stems, the investigated transect shows the lowest figure of 12 studies from Amazonian forests (Tab. 7).

Whereas diversity and density values range at the lower limits of pantropical means for lowland rain forests, basal area, however, is comparably high (BONGERS et al., 1988).

Distribution by dbh for trees $>$ $10 \mathrm{~cm}$ dbh of all plots did not differ considerably from results in other tropical forests. Often observed is a distribution of more than $60 \%$ trees with dbh $10-20 \mathrm{~cm}$, about $20 \%$ with dbh $20-30 \mathrm{~cm}, 10 \%$ with dbh $30-40$ $\mathrm{cm}$ and low percentages of the remaining diameter classes (CAMPBELL et al., 1986, LAMPRECHT, 1986).
Interesting differences offer the addition of trees below $10 \mathrm{~cm}$ dbh and the splitting into 5 by $5 \mathrm{~cm}$ classes (Fig. 4). This shows a development from plots with a high percentage of low diameter classes to a relatively homogenous distribution in the order of biomass plot 1 , biomass plot 2 , the transect, Plot A and Plot W. In the same order, an increase of the above ground biomass is observed: $97.5 \mathrm{tha}^{-1}$ in biomass plot 1, $257.6 \mathrm{t} \mathrm{ha}^{-1}$ in biomass plot 2, MARTIUS (1989) calculated a mean figure of $260 \mathrm{t} \mathrm{ha}^{-1}$ for a stand close to our forest and 107-402 $\mathrm{t} \mathrm{ha}^{-1}$ are calculated for different subplots of Plot W (WORBES, unpubl. data).

Age dating of trees from the different locations on Ilha de Marchantaria (WORBES, 1989) gives an age of less than 20 years for biomass plot 1 , about 40 years for biomass plot 2, the transect and the MARTIUS (1989) stand, and about 80 years for Plot W. The increasing age of the different stands goes along with a decreasing accessibility from the banks of the island (biomass plots 1 and 2, transect) to the center (Plot W). Local inhabitants report jute was cultivated in the region of the transect forest during the early 40 s, and the field was later abandoned. This alone explains the differences of the described trends in size class distribution, tree height, above ground biomass and diversity.

Structural analysis and age dating point out that the investigated stands are equal to young successional stages. According to the classification of BUDOWSKI (1961) biomass plot 1 represents an early secondary forest; 
Table 6. Bioelements in dry above ground biomass of a seasonal várzea forest (biomass plot 1 and 2), Ilha de Marchantaria.

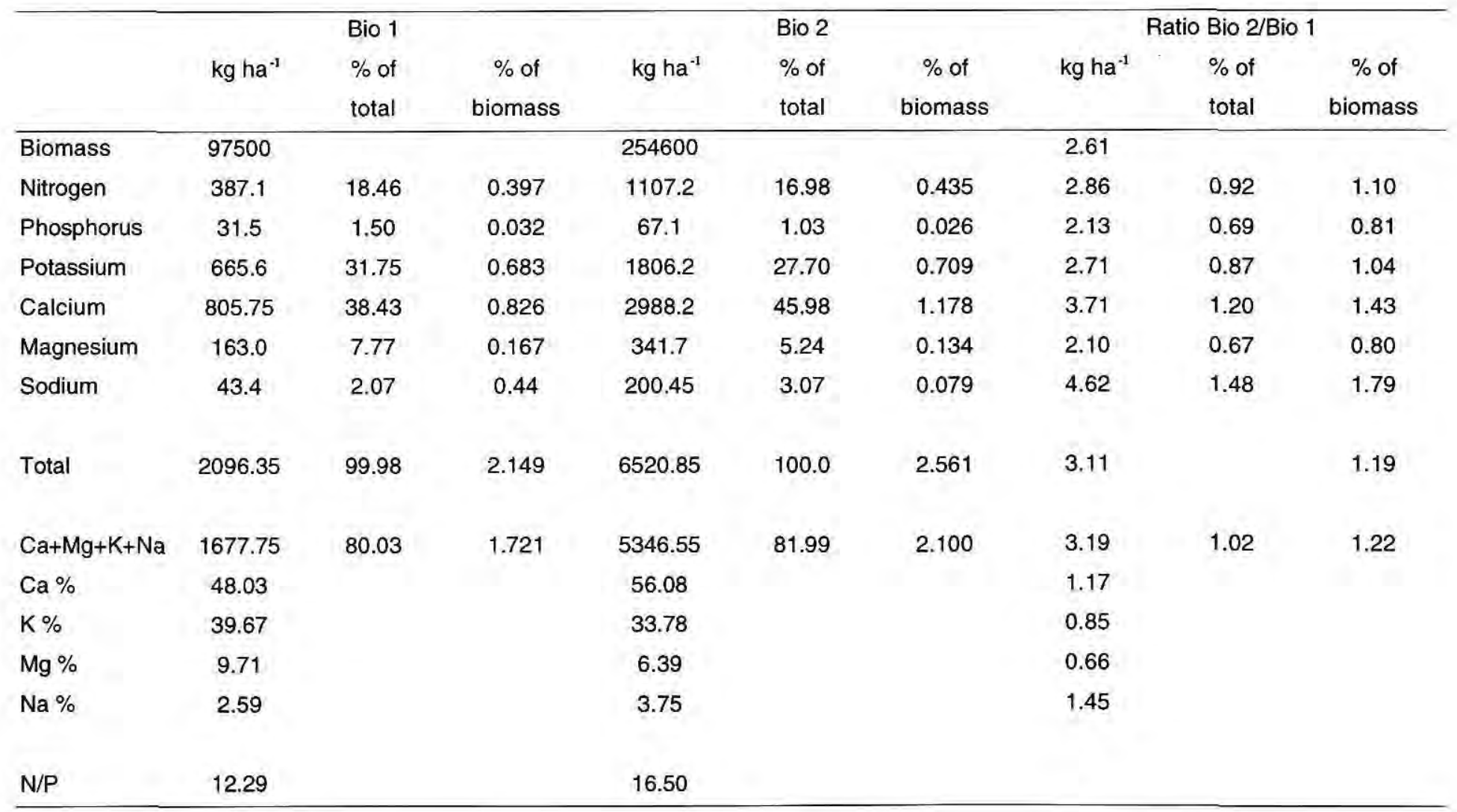


Table 7. Comparative structural data of selected Amazonian inundation and terra firme forests.

\begin{tabular}{|c|c|c|c|c|c|c|c|c|c|c|}
\hline $\begin{array}{l}\text { Forest type } \\
\text { and locality }\end{array}$ & Plot size & $\begin{array}{l}\text { dbh-limit, } \\
\mathrm{cm}\end{array}$ & $\begin{array}{l}\text { Tree density, } \\
\mathrm{N} \text { per ha }\end{array}$ & $\begin{array}{c}\text { Basal area } \\
\mathrm{m}^{2} \mathrm{ha}^{1}\end{array}$ & $\begin{array}{l}\text { N spe } \\
\text { per plot }\end{array}$ & $\begin{array}{l}\text { ecies } \\
\text { per } 100 \text { stems }\end{array}$ & leading plant family $\mathrm{N}$ & N species & $\begin{array}{l}\text { Arecaceae } \\
\% \text { of Individuals }\end{array}$ & Source \\
\hline \multicolumn{11}{|l|}{ Seasonal várzea forest } \\
\hline - llha de Marchantaria & $2100 \mathrm{~m}^{2}$ & 5 & 800 & 60 & 30 & 17.8 & Bombacaceae & 0 & & Worbes, 1983 \\
\hline \multicolumn{11}{|l|}{ - Ilha de Marchantaria } \\
\hline$=$ Transsect & $7528 m^{2}$ & 5 & 1217 & 41 & 44 & 4.8 & Leguminosae sensu lat & ato & $<1$ & This study \\
\hline$=P l o t A$ & $1500 \mathrm{~m}^{2}$ & 5 & 813 & 65 & 18 & 14.8 & Bombacaceae & 1 & $<1$ & This study \\
\hline$=$ Total study area & $9028 \mathrm{~m}^{2}$ & & 1086 & 45 & 48 & 4.9 & Leguminosae sensu late & & & This study \\
\hline \multirow[t]{2}{*}{ - Lower Solimões } & 1 ha & 5 & $325 \cdot 1270$ & $24-58$ & $69-127$ & $8.6-24.3$ & & 1 & & Revilla, 1991 \\
\hline & (15 replicates) & & & & & & & 1 & 1 & \\
\hline \multicolumn{11}{|l|}{ Tidal várzea forest } \\
\hline \multirow[t]{2}{*}{ - Guama river/Pará } & $1 \mathrm{ha}$ & 5 & 539 & n.d. & 53 & 9.8 & Arecaceae & 4 & 54 & Pires \& Koury, 1959 \\
\hline & $3.8 \mathrm{ha}$ & 10 & 483 & n.d. & 107 & 5.8 & & 7 & 32 & Pires \& Koury, 1959 \\
\hline - Guama river/Pará & $500 \mathrm{~m}^{2}$ & 2) & 5020 & n.d. & 53 & 21.1 & Arecaceae & 2 & 29 & Aubréville, 1961 \\
\hline - llha das Onças & $2500 \mathrm{~m}^{2}$ & 5 & 1576 & 40 & 51 & 12.9 & Arecaceae & 1 & 60 & Anderson et al., 1985 \\
\hline \multicolumn{11}{|l|}{ Floodplain forest } \\
\hline - Napo river/Ecuador & 1) & 10 & 417 & 35 & 149 & 35.5 & Arecaceae & 5 & 30 & Balslev et al., 1986 \\
\hline \multicolumn{11}{|l|}{ Terra firme forest } \\
\hline - Manaus & 1 ha & 8 & 735 & n.d. & 75 & 10 & Lecythidaceae & 3 & 2 & Lechthaler, 1956 \\
\hline - Manaus & 27 ha & 25 & 102 & n.d. & 431 & 15.6 & Celastraceae & & & Rodrigues, 1967 \\
\hline - Manaus & 1 ha & 15 & 358 & n.d. & 179 & 50 & Lecythidaceae & 1 & $<1$ & Prance at al., 1976 \\
\hline -Manaus & $2000 \mathrm{~m}^{2}$ & \multicolumn{2}{|c|}{$1.5 \mathrm{~m}$ height 10220} & 37 & 502 & 24.6 & & & & Klinge et al., 1975 \\
\hline - San Carlos de Rio & $1300 \mathrm{~m}^{2}$ & 1 & 11361 & 32 & 130 & 8.8 & Euphorbiaceae & 2 & $<1$ & Klinge \& Herrera, 1983 \\
\hline Negro/Venezuela & & & & & & & & & & \\
\hline
\end{tabular}

1) Point-centered quarter method 2) All plants sampled n.d. = no data 

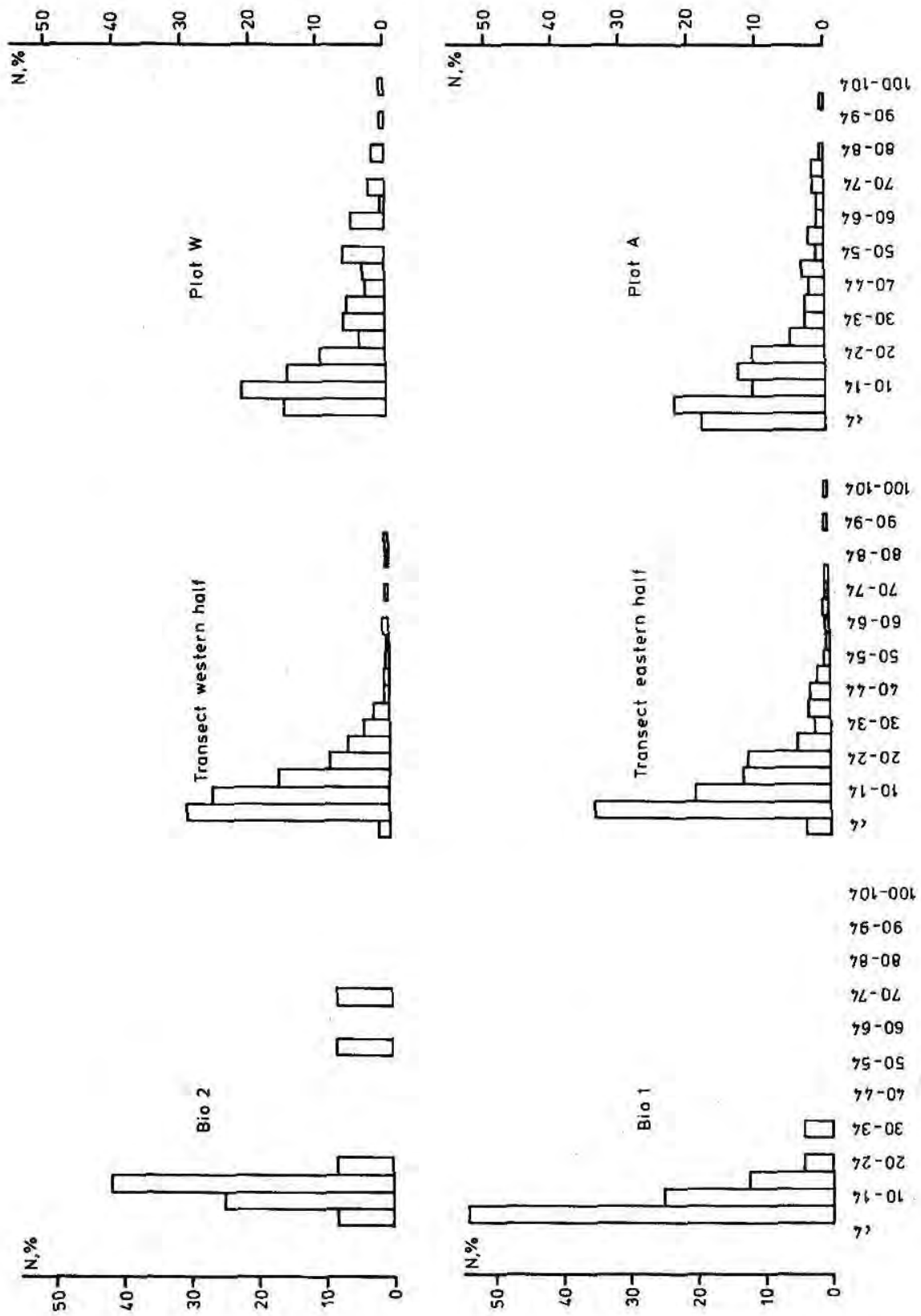

Figure 4. Relative tree density in 5 by $5 \mathrm{~cm}$ dbh-classes of the study area of a seasonal várzea forest, Ilha de Marchantaria. 
the transect and Plot W are late secondary forests. The rapid development to a relatively high diversity and to a homogenous structure in Plot A and Plot W can be traced back to often observed dynamical mechanisms on fertile soils (MAAREL, 1988). The presented study should be seen on the background of a worldwide deforestation in the tropics, which requires an increase of knowledge about reforestation and dynamical processes in tropical forests.

\section{ACKNOWLEDGEMENTS}

We thank L. Coelho, (INPA/ Manaus), for his cooperation during execution of the field work. Elke Harms made the drawings, Inge Schmidt, Gerda Lemke and Inge Dietzsch typed the various drafts of the manuscript. Dr. Karin Furch (MPI/Ploen) is heartily thanked for bioelement analyses. Prof. Ghillean T. Prance (Royal Botanical Gardens/ Kew) and Nancy Weider (Plön) kindly reviewed the English version of this paper.

\section{Literature Cited}

ANDERSON, A.B.; GELY, A;; STRUDWICK, J.; SOBEL, G.L; MA. DAS PINTO, G.C. 1985. Sistema agroflorestal na várzea do estuário amazônico (Ilha das Onças, municipio de Barcarena, Estado do Pará). Acta Amazonica, 15 (Supl. 1/2): 195-224

AUBRÉVILLE, A. 1961. Étude écologique des principales formations végétales du Brésil et contribution a la connaissance des forêts de l'Amazonie brésilienne. Centr. Techn. Forest. Trop. Nogent-sur-Mame, 268 p.

BALSLEV, H.; LUTEYN, J.; OLLGAARD, B.; HOLM-NIELSEN, L.B. 1986. Composi- tion and structure of adjacent unflooded and floodplain forest in Amazonian Ecuador. Opera Botanica, 92: 37-57

BONGERS, F; POPMA, J.; CASTILLO, J.M.; CARABIAS, J. 1988. Structure and floristic composition of the lowland rain forest of Los Tuxtlas, Mexico. Vegetatio, 74: 55-80

BRAGA, P.I.S. 1979. Subdivisão fitogeográfica, tipos de vegetação, conservação e inventário florístico da floresta amazônica. Acta Amazonica, Supl. 9: 53-80

BUDOWSKI, G. 1961. Studies on forest succession in Costa Rica and Panama. PhDthesis, New Haven, Yale Univ., 189 p.

CAMPBELL, D.G.; DALY, D.C.; PRANCE, G.T.; MACIEL, U.N. 1986. Quantitative ecological inventory of terra firme and várzea tropical forest on the Rio Xingu, Brazilian Amazon. Brittonia, 38(4): 369-393

DUCKE, A.; BLACK, G.A. 1954. Notas sôbre a fitogeografia da Amazônia brasileira. Boletim Técnico Inst. Agron. Norte, 29: 1-62

FURCH, B. 1984. Investigations concerning the inundation tolerance of trees in the varzea and the igapó. Biogeographica, 19:77-83

FURCH, K.; JUNK, W.J.; DIETERICH, J.; KOCHERT, N. 1983. Seasonal variation in the major cation ( $\mathrm{Na}, \mathrm{K}, \mathrm{Mg}$, and $\mathrm{Ca}$ ) content of the water of Lago Camaleão, an Amazonian floodplain-lake near Manaus, Brazil. Amazoniana, 8: 75-89

GESSNER, F, 1968. Zur ökologischen Problematik der Überschwemmungswälder des Amazonas. Int. Rev. ges. Hydrobiol., 53: 525-547

HUECK, K. 1966. Die Wälder Südamerikas. Fischer, Stuttgart, $422 \mathrm{p}$.

IRION, G.; ADIS, J.; JUNK, W.J; WUNDERLICH, F. 1983. Sedimentological studies of the "Ilha de Marchantaria" in the Solimões/Amazon River near Manaus. Amazoniana, 8: 1-18

JUNK, W.J. 1989. Flood tolerance and tree distribution in central Amazonian floodplains. In: HOLM-NIELSEN, L.B., NIELSEN, I.C.; BALSLEV, H. (eds). Tropical Forests - Botanical Dynamics, 
Speciation and Diversity. Academic Press, London: 47-64

JUNK, W.J.; BAYLEY, P.B.; SPARKS, R.E. 1989. The flood pulse concept in riverfloodplain systems. In: DODGE, D.P. (ed.). Proceedings of the International Large River Symposium. Can. Spec. Publ. Fish. Aquat. Sci. 106: 110-127

KLINGE, H. 1976. Bilanzierung von Hauptnährstoffen im Ökosystem tropischer Regenwald (Manaus) - vorläufige Daten. Biogeographica, 7: 59-76

KLINGE, H. 1986. Lowland Amazon forests, bioelements and geochemistry. Proc. 1st Symposium Humid Tropics, Belém 1984, 1: $333-346$

KLINGE, H.; FURCH, K. 1991. Towards the classification of Amazonian floodplains and their forests by means of biogeochemical criteria of river water and forests biomass. Interciencia, 16: 196-201.

KLINGE, H.; FURCH, K.; HARMS, E. 1984. Selected bioelements in bark and wood of native tree species from Central-Amazonian inundation forests. Amazoniana, 9: 105-117

KLINGE, H.; JUNK, W.J.; REVILLA, J.D. 1990. Status and distribution of forested wetlands in tropical South America. Forest Ecol. Management, 33/34: 81-101

KLINGE, H.; FURCH, K.; HARMS, E.; REVILLA, J.D. 1983. Foliar nutrient levels of native tree species from Central Amazonia. 1. Inundation forests. Amazoniana, 8: 19-45

KLINGE, H.; HERRERA, R. 1983. Phytomass structure of natural plant communities on spodosols in southern Venezuela: The tall Amazon Caatinga forest. Vegetatio, 53: 65-84

KLINGE, H., RODRIGUES, W.A., BRÜNIG, E.; FITTKAU, E.J. 1975. Biomass and structure in a Central Amazonian rain forest. In: GOLLEY, F.B. \& MEDINA, E. (eds). Tropical Ecological Systems. Ecological Studies 11. Springer, New York: 115-122

LAMPRECHT, H. 1972. Einige Struktumerkmale natürlicher Tropenwaldtypen und ihre waldbauliche Bedeutung. Forstwiss. Centralblatt, 91: 270-277

LAMPRECHT, H. 1986. Waldbau in den Tropen. Paul Parey, Hamburg, Berlin. 318 p.

LECHTHALER, R. 1956. Inventário das árvores de um hectare de terra firme da zona "Reserva Florestal Ducke", município de Manats. Botanica, INPA, 3; 1-5

MAAREL, E. VAN DER. 1988. Vegetation dynamics: patterns in time and space. Vegetatio, 77: 7-19

MARTIUS, C. 1989. Untersuchungen zur Ökologie des Holzabbaus durch Termiten (Isoptera) in zentralamazonischen Überschwemmungswäldern. Afra, Frankfurt, 285 p.

MEYER, U. 1991. Feinwurzelsysteme und Mykorrhizatypen als Anpassungsmechanismen in zentralamazonischen Überschwemmungswäldern - igapó und várzea. Disss. Univ. Hohenheim, $230 \mathrm{p}$.

MORI, S.A.; BOOM, B.M.; CARVALHO, A.M. DE; SANTOS, T.S. DOS. 1983. Southem Bahian moist forest. Bot. Rev., 49: 1-232

PIRES, J.M. 1976. Aspectos ecológicos da floresta amazônica. Anais II Congresso brasileire florestas tropicais, Coleção Mossoroense, 55: 235-287

PIRES, J.M. 1984. The Amazonian forest. In: SIOLI, H. (ed.). The Amazon. W. JUNK, Dordrecht: 581-602

PIRES, J.M.; KOURY, H.M. 1959. Estudo de um trecho de mata de várzea próximo de Belém. Boletim Técnico Inst. Agron. Norte, 36: 1-44

PIRES, J.M.; PRANCE, G.T. 1985. The vegetation types of the Brazilian Amazon. In: PRANCE, G.T. ; LOVEJOY, T.E. (eds.). Amazonia. Pergamon Press, Oxford: $109-145$

PRANCE, G.T. 1979. Notes on the vegetation of Amazonia III. The terminology of Amazonian forest subject to inundation. Brittonia, 31: 26-38 (Portuguese version published in Acta Amazonica, 10: 495-504, 1980)

PRANCE, G.T. 1989. American Tropical Forests. In: LIETH, H.; WERGER, M.J.A. (eds). Tropical Rain Forest Ecosystems. 
Ecosystems of the World 14B. Elsevier Publ., Amsterdam: 99-132

PRANCE, G,T,; RODRIGUES, W.A.; SILVA, M.F. DA 1976. Inventário florestal de um hectare de mata de terra firme $\mathrm{km} 30$ da estrada Manaus - Itacoatiara. Acta Amazonica, 6: 9-35

REVILLA, J.D. 1991. Aspéctos florísticos e estruturais da floresta inundável (várzea) do baixo Solimões, Amazonas, Brasil. PhD-thesis, INPA. Manaus, AM. 122 p.

RODRIGUES, W.A. 1967. Inventário florestal pilôto ao longo da estrada Manaus Itacoatiara, Estado do Amazonas: Dados preliminares. Atas Simpósio Biota Amazônica Belém 1966, 7: 257-267

SCHLÜTER, U.B, 1989. Morphologische, anatomische und physiologische Untersuchungen zur Überflutungstoleranz zweier charakteristischer Baumarten (Astrocaryum jauari und Macrolobium acaciifolium) des Weiss- und Schwarzwasserüberschwemmungswaldes bei Manaus. Diss. Univ. Kiel, 147 p.
WORBES, M. 1983. Vegetationskundliche Untersuchungen zweier Überschwemmungswälder in Zentralamazonien - vorläufige Ergebnisse. Amazoniana, 8: 47-65

WORBES, M. 1985. Structural and other adaptations to long-term flooding by trees in Central Amazonia. Amazoniana, 9: 459-484

WORBES, M. 1986. Lebensbedingungen und Holzwachstum in zentralamazonischen Überschwemmungswäldern. Scripta Geobotanica, $17: 1-112$

WORBES, M. 1989. Growth rings, increment and age of trees in inundation forests, savannas and a mountain forest in the Neotropics. IAWA Bull. n.s., IO(2): 109-122

WORBES, M.; JUNK, W.J. 1989. Dating tropical trees by means of $14 \mathrm{C}$ from bomb tests, Ecology, 70(2): 503-507 